\title{
A Coastal Vision
}

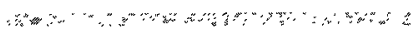

Kenneth Brink

I

is almost trite to say so, but it is true that this issue of Oceanography deals with a problem that is difficult, important, and timely.

A routine measurement system for the coastal ocean, tightly knitted with a communications, modeling and interpretation system, will deal with a range of problems that are important to our society. There is a concrete need to know about the state of the coastal ocean for issues involving shipping, fisheries, public health, research and weather prediction, to name just a few. Some aspects of a coastal observing system (such as tide gauges) are now in place, and these have served mainly to whet the appetite for a more comprehensive system. Further, there are applications for such a system that can only be imagined at this moment. For example, long (more than a couple years) in situ time series in the coastal ocean are exceedingly rare, but where we do have them, we are learning about how much conditions vary from year to year, hence how much we still need to understand. A second possible use is simply catching the public imagination. The same sort of excitement that is driven by the well-done reports on The Weather Channel ${ }^{\mathbb{\varepsilon}}$ could easily be imagined for a regular public presentation on the state of the ocean.
The range of difficulties to be addressed in designing a coastal observation system can be daunting. For one thing, there are many masters to serve: the system one designed for navigational purposes would probably not be the same that would be used for fisheries concerns. A further concern is the heterogeneity of the coastal setting: processes and concentrations can vary enormously over even very short spatial or time scales. This sort of variability makes it difficult to pick the sort of representative sampling locations that might characterize a broad area. The choices about what to measure and where thus seem to be harder in the coastal ocean than they might be in the open ocean.

So, as we consider the possibility of a coastal observing system, we can see that the need and demand are present, but that the choices that need to be made in setting up the system will be difficult. This difficulty should be taken in a positive light; it is at least partly a reflection of the breadth of support that such a system will have.

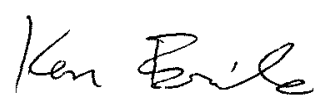

Oceanograply (ISSN 1042-8275) is published by The Oceanography Society, 1755 Massachusetts Avenue NW, Suite 700, Washington, DC 20036 USA. ( 2000, The Oceanography Society, Inc. All rights reserved. Permission is granted to copy an article in this publication for use in teaching or research. For more extensive copying, a fee of $\$ 1.00$ per article can be paid through the Copyright Clearance Center, 21 Congress Street, Salem, MA 01970. Republication, systemic reproduction, or collective redistribution of any material in this publication is permitted only with the approval of The Oceanography Society. Send change-of-address information to the Society address. Postmaster: Bulk mail postage paid Columbia, MD; Permit 1147.

\section{COMMENTS and SUGGESTIONS}

... on this special issue of Ocennography should be directed to our editorial office at tosmag@tos.org. Additional comments for specific authors can be sent to:

William Boicourt
boicourt@chssie2.lpl.umces.edu
Muriel Cole
mutiel.cole@noaa.gov
Tommy D. Dickey
tommy.dickey@opl.ucsb.edu
Scott M. Glenn
$\quad$ glenn@caribbean.rutgers.edu

$$
\begin{aligned}
& \text { Dale Haidvogel } \\
& \text { dale@incs.rutgers.edu } \\
& \text { Fred C. Klein } \\
& \text { frad.klein@mitretek.org } \\
& \text { Thomas C. Malone } \\
& \text { malone@hpl.umces.edu } \\
& \text { Dennis J. McGillicuddy } \\
& \text { dmcoillicuddy@zohoi.edu }
\end{aligned}
$$

\author{
Bruce Parker \\ bruce.parker@noaa.gov \\ Daniel Schwartz \\ schwartz@ocean.washington.edu \\ Leonard J. Walstad \\ walstad@hpl.umces.edu \\ William A. Watkins \\ wwatkins@whoi.edu
}

